August 2008

\title{
A Tribute to Stephen Feinstein: Teacher, Researcher, Friend, Colleague, and Remarkable Human Being
}

Samuel Totten

Follow this and additional works at: https://digitalcommons.usf.edu/gsp

\section{Recommended Citation}

Totten, Samuel (2008) "A Tribute to Stephen Feinstein: Teacher, Researcher, Friend, Colleague, and Remarkable Human Being," Genocide Studies and Prevention: An International Journal: Vol. 3: Iss. 2: Article 3.

Available at: https://digitalcommons.usf.edu/gsp/vol3/iss2/3

This Articles is brought to you for free and open access by the Open Access Journals at Digital Commons @ University of South Florida. It has been accepted for inclusion in Genocide Studies and Prevention: An International Journal by an authorized editor of Digital Commons @ University of South Florida. For more information, please contact digitalcommons@usf.edu. 


\title{
A Tribute to Stephen Feinstein: Teacher, Researcher, Friend, Colleague, and Remarkable Human Being
}

\author{
Samuel Totten \\ University of Arkansas, Fayetteville
}

Dr. Stephen Feinstein, a remarkable human being and Holocaust and genocide scholar, died suddenly and unexpectedly on 4 March 2008. A vibrant sixty-four years old, he was known for his wonderful sense of humor, quick smile and laugh, graciousness, and dedication to the field of genocide studies.

In the middle of a talk about genocide, he began to grope for words; those in attendance, sensing something serious was wrong, had him transported to a hospital, where he died shortly thereafter of an aortic aneurysm, having suffered cardiac failure. Among his friends, colleagues, former students, and many others, there was deep shock at his unexpected death. It just did

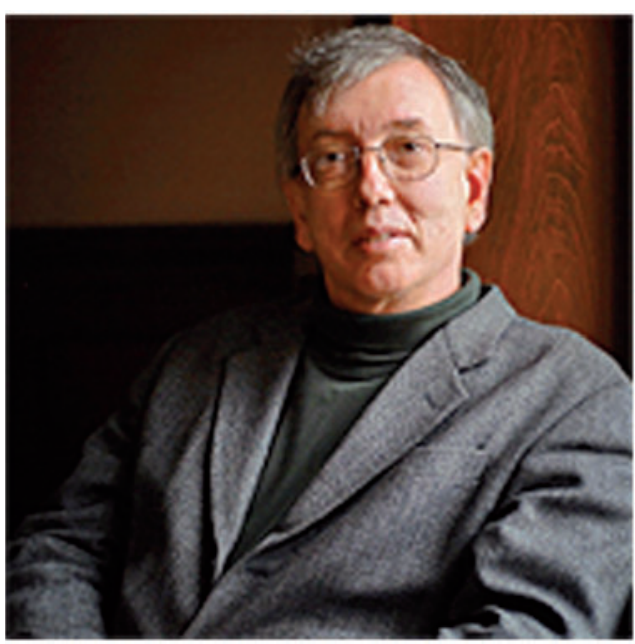
not (and does not) seem right that one who epitomized the concept of carpe diem should be taken from us all at such a relatively young age. Steve was one who truly loved life, cherished all that life had to offer, and lived life to its fullest.

His funeral, at Beth El Synagogue in St. Louis Park, was attended by more than 1,000 people-family members, friends, colleagues, and many who had the great pleasure of being among his students over the years. Tributes, condolences, and expressions of shock and sadness flowed in from across the globe upon the announcement of Steve's untimely death. People praised him for his collegiality, dedication, good humor, and passion for human rights; his teaching and research about genocide and the Holocaust; and his deep and abiding care and concern for all peoples across the globe.

Upon his retirement after thirty years as a history professor at the University of Wisconsin at River Falls, Steve began a new career at the University of Minnesota, where he founded and served as the director of UM's Center of Holocaust and Genocide Studies (CHGS). In his capacity as director, he put his heart and mind into developing thought-provoking, cutting-edge, and remarkably eclectic programsranging from conferences on the current Darfur genocide to exhibits such as Deadly Medicine, a project on the Nazi doctors developed by the US Holocaust Memorial Museum. In a very real sense, he was instrumental (through his passion, dedication, and hard work) in helping to put the University of Minnesota on the map as the home of a significant center for the study of genocide, an incipient but burgeoning field.

Samuel Totten, "A Tribute to Stephen Feinstein: Teacher, Researcher, Friend, Colleague, and Remarkable Human Being." Genocide Studies and Prevention 3, 2 (August 2008): 171-172. (C) 2008 Genocide Studies and Prevention. doi:10.3138/gsp.3.2.171 
Ellen Kennedy, a friend and colleague of Steve's at the CHGS, commented that his classes were always overflowing with students and that he made a special effort to staff the CHGS with UM undergraduates who had taken his classes and had developed an ardent interest in genocide studies. In other words, he was a keen mentor who shared his passion with his students and gave them worthwhile opportunities to channel their own passion.

Steve's area of specialty was art and genocide. He curated exhibits and wrote extensively about art and the Holocaust and genocide, providing unique insights into art and genocide-all the while encouraging other scholars to consider the unique historical and pedagogical value of such art. He was also instrumental in helping to provide educators at both the university and secondary levels with concrete methods for incorporating art of the Holocaust and genocide into their own classrooms.

Last year, the editors of GSP invited Steve to co-edit a special issue on art and genocide, and he warmly accepted our offer. Had he had the time to complete it, we know it would have been a very special issue. We also sense that it would have been a joy to work with him on such a project.

In a tribute to Steve at his funeral, colleague and noted genocide scholar Eric Weitz made the following observations about his, and our, friend Stephen Feinstein:

Everything he did was marked by a capacious vision: of understanding and concern for the tragedy not just of his own people in the Holocaust-although that was, without question, always central to his very being-but also a deep, abiding concern for others as well. He understood and fought for the establishment of human rights and humane ways of living for all peoples. He brought into the curriculum and research and programs of the University of Minnesota the history of the Holocaust, and also the history of the Armenian Genocide, the treatment, historically and today, of Native Americans, one can go on and on. And it is the reason why he was revered, even loved, in the Armenian community, for example.... All of his activities were the result of his Jewishness and his humanity-and the two were, I believe, inextricably intertwined in him. They gave him the belief that one lives in this world, one acts in this world, and one tries to leave the world just a little bit better than the way one found it. And that Steve did, deeply.

Steve Feinstein, as most genocide scholars know, is the second genocide scholar from Minnesota to have died in the past year. In late January 2007, our dear colleague, and fellow GSP editor, Eric Markusen died of pancreatic cancer. And now, a little over a year later, our dear colleague and friend Steve Feinstein has left us-his friends, his colleagues, the field of genocide studies. To say that we are bereft does not even begin to get at what we feel over what we have lost in his passing. 